\title{
pombalina
}

(8)

\section{MIR: memória narrativa}

\author{
Autor(es): $\quad$ Moreira, João Paulo \\ Publicado por: Imprensa da Universidade de Coimbra \\ URL \\ persistente: \\ URI:http://hdl.handle.net/10316.2/42372 \\ DOI: \\ DOI:https://doi.org./10.14195/978-989-26-1308-6_55
}

Accessed : $\quad$ 26-Apr-2023 16:06:03

A navegação consulta e descarregamento dos títulos inseridos nas Bibliotecas Digitais UC Digitalis, UC Pombalina e UC Impactum, pressupõem a aceitação plena e sem reservas dos Termos e Condições de Uso destas Bibliotecas Digitais, disponíveis em https://digitalis.uc.pt/pt-pt/termos.

Conforme exposto nos referidos Termos e Condições de Uso, o descarregamento de títulos de acesso restrito requer uma licença válida de autorização devendo o utilizador aceder ao(s) documento(s) a partir de um endereço de IP da instituição detentora da supramencionada licença.

Ao utilizador é apenas permitido o descarregamento para uso pessoal, pelo que o emprego do(s) título(s) descarregado(s) para outro fim, designadamente comercial, carece de autorização do respetivo autor ou editor da obra.

Na medida em que todas as obras da UC Digitalis se encontram protegidas pelo Código do Direito de Autor e Direitos Conexos e demais legislação aplicável, toda a cópia, parcial ou total, deste documento, nos casos em que é legalmente admitida, deverá conter ou fazer-se acompanhar por este aviso. 



\section{I R : MEM Ó R I NARRATIVA}

João Paulo Moreira

Por feliz confluência histórica, o seu regresso dos Estados Unidos da América, de onde trouxe modelos de vivência académica baseados na partilha despreconceituosa do saber e na valorização do contributo original e autónomo do estudioso - fosse ele discente ou docente - coincidiu no tempo com o agitado mas estimulantíssimo final da primeira metade da década de setenta, período de inquietação dos espíritos e de grandes desafios e interrogações a todos os níveis e nas mais miúdas voltas do dia-a-dia. A prática letiva de Maria Irene Ramalho parecia talhada para esses tempos conturbados mas apaixonantes. Desconcertava e seduzia alunos e alunas porque lhes queria saber as opiniões, escutava-as com respeito, incorporava-as na textura da aula. A lição nem com o sumário ficava verdadeiramente encerrada, porque a discussão e o convite à dissensão permaneciam em aberto. Não menos sedutor, contudo - e particularmente espantoso para a época - era o facto de, a par dos clássicos e da produção teórica pertinente, dominar a literatura primária mais recente, e, mais do que isso, trazer para os programas de licenciatura obras de autores não só vivos como controversos. Com o tempo, essas obras e autores viriam a ser integrados nos currículos de pós-licenciatura e em projetos de doutoramento, e isso hoje parece-nos natural, quando na época estava longe de o ser. 
Foi, assim, precioso privilégio pertencer ao círculo da amizade que veio depois, cimentada em décadas de convívio. Ao mesmo tempo, na relação profissional, foram constantes a confiança, o apoio e o incentivo. Ao longo dos anos pude, em incontáveis ocasiões, voltar a sentar-me no lugar do pupilo, em seminários e palestras que produziu sobre uma paleta infinda de temas, canónicos e dos outros. E se isso não bastasse, a admiração pela Maria Irene, pela sua energia inesgotável e pela imensa dedicação à causa do saber posto em comum, ficaria ainda, e mais uma vez, indelevelmente gravada em mim - como em tantos, tantos mais - graças à iniciativa entusiasmante que foi a organização dos Encontros Internacionais de Poetas, essa aventura corajosa que repercutiria fundo na escola e nos espíritos que mobilizou, e que continua a produzir ecos de carinho e reconhecimento nas mais distantes e inesperadas paragens.

É, enfim, privilégio também que me seja permitido juntar a voz à presente homenagem à Maria Irene e testemunhar que continuo, desde essas primeiras aulas nos bancos da licenciatura, um seu sempre discípulo, sempre aprendiz, sempre rendido ao exemplo de curiosidade inquieta, de humildade e generosidade. 